УДК 261

DOI 10.35423/2078-8142.2020.1.14

\author{
В. В. Бринов, \\ науковий співробітник \\ Національного педагогічного університету \\ імені М. П. Драгоманова \\ м. Київ, Украӥна \\ e-mail:vv.brynov@gmail.com \\ ORCID: https://orcid.org/0000-0003-3714-6524
}

\title{
СДНАЛЬНА РОЛЬ РЕЛІГІЇ У СУСПІЛЬСТВІ З ТОЧКИ ЗОРУ ХРИСТИЯНСЬКОГО РЕАЛІЗМУ
}

У статті розглянуто роль релігії, як суспільної ідеології, з точки зору християнського реалізму Рейнхольда Нібура. Досліджено вплив релігії на суспільство через зміну системи иінностей окремих індивідів. Встановлено, щзо суспільна користь релігії визначається проявом духу каяття, який запобігає індивідуальному егоїзму і гордості. Описано роль любові як підсилюючого чинника у близьких суспільних відносинах. Встановлено, щь через індивідуалістичний характер відносин між Богом та індивідом релігія має обмежений вплив на суспільство. Причиною обмеженості релігії $\epsilon$ більша сила колективного егоїзму, порівняно з індивідуальними чеснотами. Визначено, що ідеалістичні релігійні спільноти у суспільстві демонструють три основні моделі поведінки: індиферентність, поразництво та сентиментальність. Продемонстровано релігійний характер міленіальних та апокаліптичних очікувань у всіх ідеологіях.

Ключові слова: релігія, суспільство, каяття, колективний егоїзм, міленаризм, християнський реалізм, Рейнхольд Нібур.

Релігія є невід'ємним супутником людського суспільства, а релігійні спільноти $є$ найбільш чисельними серед суспільних об'єднань. Водночас, людство постійно стикається 3 глобальними викликами зсередини суспільства, через прояви зла та несправедливості. Тому важливо проаналізувати можливості релігійних ідей та

(C) Бринов В. В., 2020 
позитивний вплив релігії на суспільство з метою більш ефективної суспільної комунікації між суспільством і релігійними інституціями. Релігійний світогляд, водночас, спонукає людей до ідеалізації світу, відносин між людьми та перспектив людства в цілому. Тому важливо проаналізувати перспективи релігійного ідеалізму.

Соціально-політична теологія є важливим інструментом пояснення відносин між церквою, як релігійною спільнотою, та суспільством, а також між індивідом, як окремою особою, що має волю та моральні якості, і суспільством, як втіленням колективних інтересів людей. На соціальні та політичні питання намагалися відповісти Карл Барт, Дітріх Бонхеффер, Рейнхольд Нібур з точки зору богослов'я кризи та переосмислення ідеалістичних ідей модерну. Також з різних боків давали відповіді на соціальні питання Густаво Гутьєрpec, Юрген Мольтман, Карл Ранер, Жак Марітен та інші.

Мета статті полягає в аналізі ролі релігії як інструменту трансформації суспільства, та впливу релігії на вирішення суспільних проблем, з точки зору християнського реалізму Рейнхольда Нібура.

Релігійні ідеалісти вірять, що ідеальне суспільство буде втілене шляхом відродження релігіі, і це дасть людям сили і ресурси для того, щоб витягнути суспільство із соціального хаосу. Р. Нібур зазначає, що такі мрії притаманні релігії навіть тоді, коли вона перебуває в опозиції до пануючого у суспільстві світогляду, i «пануюча ідеологія розглядає релігію швидше як перешкоду здоланню соціальних хвороб, ніж допомогу» [1, с. 51]. Він відзначає: «Якщо визнання егоїзму $є$ необхідною умовою пом'якшення його сили та зменшення його антисоціальних наслідків у суспільстві, релігія повинна мати домінуючий вплив у соціалізації людини, бо релігія плідна саме духом каяття» [1, с. 51].

Коли релігійна людина відчуває себе під наглядом Всезнаючого Бога та порівнює свою волю з волею Божою, вона відчуває сором за свою наглість та егоцентричне життя. Р. Нібур визначає відчуття скорботи та каяття як один 3 головних мотивів релігійного смирення та вираження релігійного життя [1, с. 51-52]. У своїй сутності релігія є відчуттям Абсолюту. Але якщо уявляти Абсолют 3 перспективи людського мислення та людських етичних категорій, це викривляє моральну перспективу людства. Коли аналізуються події історії, то кожний людський вчинок можна визнати єдино правиль192

H.Skovoroda Institute of Philosophy of the NAS of Ukraine 
ним з точки зору людської моралі, якщо правильно побудувати його контекст та порівняти 3 іншими, менш доброчесними варіантами подій.

Водночас, «посилання релігії на абсолют усуває ці часткові перспективи та передчасні виправдання вчинків» [1, с. 52]. Звісно, можна інтерпретувати релігію з точки зору збоченої моралі, тоді «помилки і пороки людей будуть вдягнені релігією у божественну пишність та прикраси абсолюту». Тому Р. Нібур вважає головним завданням «високих» релігій забезпечення доброчесності у трактуванні та посилення осуду за егоїзм.

Релігійна уява, прагнучи до кінцевої мети та точки відліку моральних потреб життя, знаходить підтримку у прагненнях до абсолюту у нескінченності та величі фізичного світу. Р. Нібур описує всемогутність Бога як таку, яка «спостерігається у світі природи та вкладає свій моральний характер якостями абсолюту і перетворює його на святість» [1, с. 53].

Через те, що абсолютна могутність і досконала святість несумісні між собою, всі релігії містять «ноту раціональної абсурдності», якої бажають позбутися більш раціональні богословські системи. Проте, це неможливо без втрати релігійної життєздатності. «Релігійна совість чутлива не лише через те, що недосконалість розглядається у світлі Абсолюту, а й тому, що обов'язки Абсолюту відчуваються як обов'язки перед людиною» [1, с. 53]. Свята воля є особистою волею, і це можливо завдяки використанню символів, які походять 3 людської персональності, для того, щоб пояснити Абсолют і продемонструвати його моральні здатності. Тоді моральні відносини відчуваються сильніше та переносяться на міжособові відносини.

В якості таких символів Р. Нібур наводить монархію, королів, націю, але найсильнішим символом є людина, яка живе. У релігії моральні зобов'язання, втрачені в історичних абстракціях, відчуваються як зобов'язання перед верховною особою. Таким чином, персоналії та святість Бога забезпечують релігійну людину двома запобіжниками перед волею-до-влади та посилюють іiі моральні здібностi.

Історія релігії доводить ефективність релігійного просвітлення людської совісті та демонстрації гріховності егоїстичної стурбованості. Р. Нібур ствердждує, що все, відкрите сучасними психолога- 
ми про проблеми егоцентричності, раніше було передбачене у пророцтвах великих містиків під час класичних періодів релігії [1, с. 54]. Аскеза, що вважається великим пороком і одночасно великою чеснотою релігії, підтверджує сенситивне втілення зла свавілля. Шопенгауер описує аскезу як відмову від волі-до-життя, що виявляється у двох принципах: «Воля людини змінюється, і вона більше не стверджує свою сутність, а відкидає ії... Повна і добровільна цнотливість $є$ першим кроком до аскези, або відмови від волі-до-життя... Аскеза проявляється, далі, у добровільній, навмисній бідності, яка не настає тільки через те, що власність роздається задля полегшення чужих страждань, але $\epsilon$ сама по собі метою та повинна служити засобом постійного умертвлення волі, щоб задовільнення бажань, смак життя не збудили знов волю, до якої самопізнання сповнилось відрази» [4, с. 474-476].

Містики, які намагалися задовольнити прагнення до абсолютної досконалості через аскетичні практики, потрапили у складнішу та більш ірраціональну ситуацію: вони зруйнували життя і суспільство у процесі його очищення. Р. Нібур відзначає, що християнські та буддистські містики, які марно намагались відокремити егоїстичні бажання від волі-до-життя, зупинились в одному кроці від фізичного самознищення у спробах знищити бажання. Коли Христос каже: «Хто душу свою зберігає, той погубить іï, хто ж за Мене погубить душу свою, той знайде їі» (Матвія 10:39), то Його слова здаються парадоксальними, проте «релігійна напруженість, яка підштовхує людей до аскези, вирішується шляхом осуду пошуків себе як мети у житті, але дозволяє самореалізацію як додатковий результат самозречення» [1, с. 56]. Цей парадокс зберіг християнство від песимістичної відмови від життя, яка притаманна індуїзму та буддизму. Проте відмінність між західними та східними релігіями полягає лише у мірі аскетизму, який залишається головною ознакою всіх релігій.

Іншим моральним ресурсом релігії $є$ наголос на любові як найвищій чесноті. Раціональна етика спрямовується на справедливість, а релігійна етика встановлює любов як ідеал. Раціональна етика намагається відповісти на потреби людини та ближніх рівною мірою, релігійна етика (особливо християнська) вважає, що потреби навколишніх потрібно задовольняти безвідносно розрахунків потреб інших. Р. Нібур зауважує: «наголос на любові $є$ ще одним результа194

H.Skovoroda Institute of Philosophy of the NAS of Ukraine 
том релігійного відчуття Абсолюту» [1, с. 57]. Частково релігійний ідеал любові живиться і підтримується поглядом на душу ближнього $з$ перспективи абсолюту та трансцендентності. Якщо дивитись на ближнього як на дитя Боже, то можна догоджати Богові через служіння ближньому. Христос казав: «Що ви зробили одному з малих сих, то ви зробили Мені» (Матвія 25:40). «Таке релігійне розуміння походить від здатності релігійної уяви побачити наочне і недосконале з абсолютної і трансцендентної перспективи» [1, с. 58]. Саме осягнення цієї істини дає змогу щиро служити іншим та віддавати їм свою любов.

Але релігійна оцінка особистості проявляється не лише у містичному підході до людської природи, а й у більш раціональних формах релігії. Серед них Р. Нібур відзначає доктрину братерства у стоїцизмі, яка походить зі стоїчного пантеїзму, максими Канта, раціональний християнський ідеалізм тощо. Р. Нібур відзначає, що глибока пошана до людської особистості надихала християнських діячів на соціальні реформи, зокрема Вільяма Еллері Чаннінга на аболіціонізм. Джон Вулман теж був аболіціоністом, але не з раціональної, а з містичної позиції: на його думку, людина не може бути рабом, тому що у людській особистості присутні грані божественного [1, с. 59].

Інтроспективний характер релігії, що виявляється у дусі каяття, також передається духові любові. Егоїстичні імпульси розпізнаються та аналізуються на глибших рівнях релігійної інтроверсії. Вони засуджуються більш суворо через те, що критичний погляд особи через містичний досвід «перетворюється на засуджуючий погляд Бога» [1, с. 60]. При погляді ззовні, людські вчинки можуть здаватись більш доброчесними через те, що їхні мотиви приховані. Навіть вчинки 3 егоїстичних мотивів можуть заохочуватись суспільством. Але при інтроспективному погляді на вчинки неможлива ні моральна плутанина, ні таке заохочення. Жорсткий внутрішній аналіз не залишає місця навіть для домішок егоїзму у добрих намірах чи діях, тим більше неможливе соціальне виправдання егоїзму.

Незважаючи на те, що релігія переважно займається Абсолютом 3 точки зору індивіда, вона все ж може утворити і абсолютне суспільство, в якому втіляться ідеали любові та справедливості. Р. Нібур акцентує наявність міленіальних надій у кожній життєздат- 
ній релігії [1, с. 60]. Пророцтва Ісаї про день, коли лев буде гратись 3 ягнятком (Ісаї 11:6-9), Р. Нібур описує як «скасування природного закону, який спонукає сильного пожирати слабкого» [1, с. 61]. У порівнянні зі стародавніми релігіями, єврейські очікування тисячолітнього Царства на цій землі $є$ геніальними та проявом релігійного одкровення. Коли релігія починає співвідносити себе до проблем суспільства, завжди з'являються міленіальні очікування, які засуджують нерівність та надихають людей боротись проти неї з більшими зусиллями, щоб поновити справедливість.

Р. Нібур твердить, що без міленіальної перспективи, коли передбачаються тільки безпосередні перспективи та наявні реалії, побудова справедливого суспільства виглядає безнадійною справою [1, с. 61]. Комуністична ідея про суспільство ідеальної рівності є секулярною, але має повністю міленіальний характер, як різновид класичної релігійної мрії. Хоч ця ідея по суті є секуляризованою версією релігійної надії, комуністичну ідею вирізняє наголос на катастрофі, яка передує появі ідеального суспільства. Вона песимістично дивиться на перспективи сучасного суспільства і заперечує міленаризм як наслідок еволюційного розвитку суспільства, проте, як і в усіх релігіях, «надії комунізму проростають з відчаю, і нове суспільство так само виникає на уламках катастрофи» [1, с. 62].

Еволюційний міленаризм завжди був надією привілейованих та заможних класів, які вважають себе занадто раціональними, щоб повірити в раптову появу Абсолюту в історії. «Для них ідеалом є сама історія, а шляхом до тріумфу - наполеглива праця» [1, с. 62]. Вони ототожнюють Бога 3 природою, а ідеальне - 3 реальним через те, що вони не настільки стикаються зі стражданням у своєму житті, як бідні і знедолені. Заможні не приймають катастрофічного погляду на історію і майбутнє. Із тих самих міркувань більш заможні пролетарі замінюють катастрофічний марксизм еволюційним соціалізмом.

Тому Р. Нібур називає релігію «цитаделлю надії, яка побудована на межі відчаю». Люди схильні дивитись на моральні дії із самозаспокоєнням доти, доки не бачать їх з абсолютної перспективи. Але цей абсолютизм, який підштовхує до відчаю, відновлює їхню надію. «Релігійна людина вірить, що Бог, який засуджує історію, все таки викупить історію» [1, с. 62]. 
Хоча потенціал моральних ресурсів релігії дає надію на відродження суспільства через морально-релігійні якості, варто пам'ятати про фундаментальні обмеження релігії. Вона перш за все спрямована на очищення особистого життя індивіда та на відновлення цілісності близьких суспільних відносин, як, наприклад, родинні чи сімейні. Тому за допомогою релігії важко вирішувати складні соціальні або політичні проблеми. Саме через це суспільство схильне відкидати релігію як таку, що не пропонує швидкого вирішення гострих проблем. Але релігійні сентименталісти, які вважають, що мають ліки від усіх людських проблем, нічим не кращі від тих, хто відмовляється від релігіі. Обидві ці категорії людей намагаються використати релігію не за призначенням.

Релігійне відчуття Абсолюту визначає волю-до-життя і волюдо-влади, підпорядковуючи їх абсолютній волі, та наділяє інших індивідів трансцендентними цінностями. Через це воно застосовує до себе вищі вимоги. Р. Нібур називає це «моральним здобутком» [1, с. 63]. Але крім цього релігія призводить до абсолютизації особистості, сублімації волі-до-життя. Незважаючи на велич та трансцендентність Бога, Він тим не менш пов'язаний з людиною своїми якостями та інтересом у людині. Його якості - це людські чесноти, зведені в абсолютний ступінь. Його зацікавленість у людях не вщухає, навіть коли Його описують як «цілковито Іншого» у теології К. Барта [2, с. 90]. Р. Нібур відзначає, що «релігія одночасно є проявом смирення перед Абсолютом і самоствердженням у категоріях Абсолюту» [1, с. 64].

Секулярні радикали, які називають релігію «опієм для народу», мотивують свою позицію тим, що за допомогою релігії людина шукає остаточного задоволення в надприродному та надісторичному світі. Але, водночас, релігійне освячення особистого життя і волі може зробити його більш рішучою силою в історичній ситуації. Цікавим аспектом людського прагнення до Абсолюту є те, що в історичному вимірі має значення тільки контраст між божественним та людським. Усі інші контрасти між добрим і злим губляться в історичному масштабі. Гріх стає просто непослухом Богові, і не чим іншим.

Р. Нібур зауважує, що у Бартовому відродженні лютеранської ортодоксії релігійний досвід практично вичерпаний у сенсі каяття. 
«Наголос на відмінностях між святістю Бога та гріховністю людини настільки абсолютний, що людина засуджується не за конкретні провини проти життя спільноти, а за те, що вона - людина, а не божественна» [1, с. 68].

Приводячи на противагу теології К. Барта позицію Шлейєрмахера, Р. Нібур називає його «страховиськом Бартіанців». Шлейєрмахер стверджує: «Релігія це життя у нескінченній природі цілого, всеєдиному, в Бозі, - життя, що володіє Богом у всім і всьому в Бозі... А ваша етика, наука про поведінку, прагне розрізняти окремі моменти людських дій і творчості і розвивати їх у визначену і гармонійну систему. Але благочестива людина зізнається вам, що вона про це нічого не знає. Вона роздумує про людську поведінку, але ці роздуми не тотожні тим, з яких виникає етична система. Благочестива людина шукає і відчуває тільки одне - саме дію Бога у людях» [3, c. 75].

Р. Нібур зазначає, що приховано пантеїстична позиція Шлейєрмахера є діаметрально протилежною до Бартових концепцій божественної трансцендентності, і вона призводить до того, що головним релігійним відчуттям стає не розкаяння, а пошук [1, с. 68]. Проте обидві позиції сходяться у тому, що розділяють етику та релігію. Тенденція релігії відкидати відтінки та градації морального життя, змальовуючи все тільки у контрасті між сяйвом божественної святості та темрявою грішного світу, проявляється в усі часи. Це дуже швидко призводить до моральної, соціальної та політичної індиферентності.

«Людина, i особливо суспільство, вважаються надто пов'язаними з гріхами цієї землі, щоб мати можливість спасіння в усіх моральних сенсах» [1, с. 70]. Якщо вважати, що індивід спасається милістю Божою, а суспільство залишається дияволу, то суспільні проблеми у такому формулюванні взагалі не можуть бути розв'язані в жодній етичній системі. Суспільна несправедливість настільки контрастує 3 моральними ідеалами релігії, що вразливі релігійні особи впадають у відчай і намагаються ізолювати себе від зла. У такому разі пошук Бога супроводжується асоціальною аскезою, і прагне ізоляції від суспільства. Тому гріх у суспільстві не можна розглядати суто з релігійної точки зору. 
Але все таки релігія намагається вирішувати соціальні проблеми та давати відповіді на складні запитання. У таких випадках дух любові краще пояснює наявні ресурси та обмеження релігії, ніж почуття розкаяння. Християнство підштовхує людей проявляти любов до всіх, а не тільки до споріднених людей. Христос казав: «Коли бо ви любите тих, хто вас любить, то яку нагороду ви маєте?» (Матвія 5:46) Споглядаючи на людей $з$ трансцендентної перспективи, всі вони вважаються нашими братами та сестрами. Такий погляд руйнує бар'єри та чинники, що розділяють, об'єднуючи всесвітнє людське суспільство в єдину велику сім'ю. Цей трансцендентний погляд допоміг багатьом релігійним ідеалістам здолати національні, расові та класові розбіжності.

Р. Нібур зауважує, що визначні релігійні провидці та святі покладали надію на відродження суспільства через ефективне поширення у суспільстві універсалізму любові, який прихований у релігійній моралі [1, с. 72]. Ще за часів ранньої церкви християнські спільноти мали надію на те, що християнська любов один до одного стане прикладом для наслідування всьому світовому суспільству. Р. Нібур пише, що у наші часи цю ідею особливо палко захищають невеликі церковні деномінації. В Україні до таких деномінацій можна віднести ізольовані протестантські об'єднання, яки пішли у глибоке підпілля в часи релігійних переслідувань у СРСР.

На практиці це означає, що релігія повинна посилити та поширити суспільні стосунки, які природно належать до вузького кола. Але $є$ певні обмеження для таких стосунків. Не можна очікувати, що всі люди стануть духовними більшою мірою, ніж очікується, шо вони будуть раціональними. Нібур вважає, що $є$ невелика частка тих, хто досягає певного довершення у духовності або раціональності. «Вони матимуть значний вплив на суспільне життя, проте на досягненнях невеликої групи людей не можна будувати політичну структуру суспільства» [1, с. 73]. Релігія може консолідувати добрі наміри та спрямувати їх у волю та розум, роблячи характер індивіда добрим та менш залежним від зміни почуттів. Проте добрі наміри, як і любов, повинні бути спрямовані на певний об'єкт, якому це добро буде адресоване. Якщо такого об'єкта немає, або складність суспільної ситуації потребує виваженого аналізу та раціональних дій, 
то імпульс добрих намірів може згаснути через неможливість ці наміри виразити до конкретного об'єкту.

Усі ці недоліки духу любові, які проявляються за потреби розв’язання складних питань у відносинах між індивідами, стають ще яскравішими під час розгляду відносин суспільних груп. Р. Нібур твердить: «Якщо націям та іншим великим суспільним групам важко дотримуватись принципів справедливості, то для прояву принципів любові вони придатні ще менше, тому що любов потребує більше зусиль, ніж справедливість» [1, с. 74-75]. Принцип «люби ближнього, як самого себе» неможливо виконати по відношенню до осіб, 3 якими немає тісного зв'язку, через обмеженість розуму людини, який не може уявити себе на місці чужої людини, щоб служити іiі потребам. Ці люди фактично не є ближніми, і Бог це розумів, коли установлював закони любові.

Р. Нібур зазначає, що навіть якби знайшлась така спільнота, яка на національному рівні виконувала б закон любові, це призвело б до зростання національної гордості і проявів напруження вже на міжнаціональному рівні [1, с. 75].

Раніше було розглянуто недоліки суто релігійного підходу до концепції гріха, яка підштовхує релігійних ідеалістів до соціальної та політичної індиферентності. Крім цього, неможливість втілити релігійні ідеали у політичних та економічних відносинах може спонукати до поразництва і сентименталізму.

Поразництво знаходиться дуже близько до індиферентності. Воно проявляється як визнання неможливості впливати на суспільні процеси. Р. Нібур зазначає: «Рання Церква мала поразницьке ставлення до світу, вважаючи його проклятим, та виражала оптимізм у міленіальній надії» [1, с. 76]. Корінь поразництва полягає у визначенні ідеалів з релігійної точки зору, а не з точки зору суспільної моралі. Від людей вимагається абсолютна любов, абсолютна жертовність, абсолютна надія тощо. Політичні та економічні відносини явно виходять за межі релігійно-моральних ідеалів. У часи ранньої Церкви люди сприймали рабство, несправедливість, соціальну нерівність, війни як похідні від «природного закону, який Бог призначив для грішного світу» [1, с. 76]. Природний закон вважався нижчим за Божий закон, тому люди просто очікували, коли Бог прийде і змі- 
нить суспільний порядок на справедливий, безгрішний i не пов'язаний зі стражданнями.

Навіть у часи Реформації закон любові сприймався і протестантами, і католиками не як соціальний, а як релігійний, який встановлював рівність перед Богом і регулював відносини у церкві як релігійній спільноті. На соціальну справедливість закон любові не поширював ні Лютер, ні католицькі богослови. Те саме можна сказати про ранню Церкву і рабовласництво. Закон любові по відношенню до рабів не означав, що потрібно змінити їх соціальний статус. Р. Нібур визначає поразництво як «Занадто послідовний дуалізм у категоріях «Бог - світ», «дух - тіло». Він доводить релігійну людину до відчаю через те, що на економічне та політичне суспільне життя розумові та моральні запобіжники мають значно менший вплив, ніж на індивідуальне життя» [1, с. 78].

Проте, якщо поразництво $є$ недоліком ортодоксальних християнських течій, то сентименталізм $є$ пороком ліберального християнства. Коли ліберали підлаштовували віру до духу сучасної культури, то вона вбирала у себе еволюційний оптимізм та романтичне перебільшення людських чеснот, які були властиві філософам Просвітництва й епохи романтизму. Саме сентименталізм є причиною таких проголошень ліберальних проповідників, як «Я - такий, який $\epsilon$, і цього достатньо», «Ми боги, наші обличчя осяяні», «Я святий ззовні та зсередини, все, чого я торкаюсь, стає святим», та ін.

Крім того, привілейовані та заможні класи менше здатні сприймати справжній характер соціальної несправедливості, ніж ті, котрі від цієї несправедливості потерпають. По-перше, це відбувається через певне лицемірство, по-друге, через те, що привілейовані класи мають зиск від несправедливості і дивляться на неї з іншого боку. Але така несвідома сентиментальність може бути цілком справедливо розглянута як свідоме лицемірство та моральне збочення заради матеріального зиску. Р. Нібур відзначав, що позаяк ліберальний протестантизм в цілому є релігією привілейованих класів західної цивілізації, не дивно, що його прибічники, які будують суспільство несправедливості, повинні бути цинічно оцінені та засуджені за лицемірство перед тими, що їх гіркий соціальний досвід знищує сентиментальність та ілюзію комфорту [1, с. 80] 
Підсумовуючи, можна побачити багато викликів перед релігією як інструментом та джерелом натхнення для встановлення соціальної справедливості. Кожне прагнення соціальної справедливості буде мати у собі релігійний елемент. Релігія завжди буде намагатись посилити ідею справедливості ідеалами любові, і це запобігатиме перетворенню політико-етичної ідеї справедливості на суто політичну. Тому етичні ідеї повинні містити у собі релігійні елементи, $\mathrm{i}$ надія на справедливе суспільство - релігійно надихатись.

Р. Нібур відзначає: «Без релігійної надії та прагнення жодне суспільство не матиме мужності, щоб подолати відчай та спробувати неможливе; якщо дивитись на справедливе суспільство як на неможливе, проте яке може бути наближене тими, хто не вважає його неможливим» [1, с. 81]. Повна сила релігійної віри не буде спрямована на побудову справедливого суспільства, тому що найвищі релігійні одкровення походять від індивідуальних переживань людей. Якщо вони і будуть осягнуті, то їх втілять у близьких релігійних спільнотах, в яких ідеї окремих людей втілюються, проте не завойовують суспільство.

Осмислення необхідності Божої допомоги прийде до людей у той день, коли буде побудовано нове справедливе суспільство, i з'ясується, що воно несправедливе. Тому люди повинні втілювати індивідуальні чесноти та ідеали у повсякденному житті, але розуміти, що для докорінної зміни суспільства необхідне втручання трансцендентного.

Отже, підсумовуючи, відзначимо, що у статті розглянуто позицію християнського реалізму щодо релігії як інструменту для гармонійного життя у суспільстві. Встановлено, що суспільну цінність має релігійний дух каяття, який зменшує егоїзм та запобігає гордості. Наголошено, що суспільна роль релігії полягає у засудженні егоїзму та проявів гордості. Зазначено, що найвищою релігійною чеснотою, яка посилює суспільні імпульси, є прояв любові до іншого.

Описано обмеженість застосування релігійних ресурсів у великих суспільствах через релігійну спрямованість Абсолюту на особистість. Зроблено наголос на релігійній природі міленіальних очікувань, що виявляються навіть у секулярних світоглядах. Розглянуто відмінність між релігійною мораллю та етикою. Проаналізовано недоліки релігійно-ідеалістичного підходу до реформування суспі202

H.Skovoroda Institute of Philosophy of the NAS of Ukraine 
льства. Описано три моделі суспільної поведінки релігійних спільнот: індиферентну, поразницьку та сентиментальну. Наголошено на необхідності втручання Бога як Абсолюту для втілення міленіальних очікувань людства.

Перспективи дослідження полягають в аналізі української публічної теології з точки зору християнського реалізму, а також у подальшому зменшенні ідеалістичних очікувань в українському суспільстві.

\section{ЛITEPATУРA}

1. Niebuhr R. Moral Man and Immoral Society. New York: Charles Scribner's Sons, 1960.

2. Гренц С., Олсон Р. Богословие и богословы XX века. Черкассы : Коллоквиум, 2011.

3. Шлейермахер Ф. Речи о религии к образованным людям, ее презирающим. Санкт-Петербург : Алетейя, 1994.

4. Шопенгауэр А. Мир как воля и представление. Т. 1. Москва: Наука, 1993.

\section{REFERENCES}

Niebuhr, R. (1960). Moral Man and Immoral Society. New York: Charles Scribner's Sons.

Grenz, S., Olson, R. (2011). Twentieth Century Theology. Cherkasy: Kollokvium. [In Russian].

Schleiermacher, F. (1994). On Religion: Speeches to its Cultured Despisers. Saint-Petersburg: Aleteja. [In Russian].

Shopenhauer, A. (1993). The World as Will and Representation, vol.1. Moscow: Nauka. [In Russian].

\section{Vitalii Brynov}

Research Assistant, National Pedagogical Dragomanov University; Kyiv, Ukraine; e-mail:vv.brynov@gmail.com; ORCID: https://orcid.org/0000-00033714-6524 


\title{
Uniting role of religion in society from the Christian realism's point of view
}

\begin{abstract}
The article considers the role of religion, as a social ideology, from the Christian realism of Reinhold Niebuhr's point of view. It is investigated that religion impacts on society through the changes in individual's system of values. It is established that the public good of religion is determined by the demonstration of the spirit of contrition, which prevents individual egoism and pride. The role of love as an enhancing factor in close social relations is described. It is shown that asceticism has religious roots, but egoistic and selfish nature, depending on understanding term of sin. It is established that religion has limited influence on society due to the individualistic nature of the relationships between God and the individual. The reason of the limited religion influence is the greater power of collective egoism, comparing with individual virtues. It is determined that idealistic religious communities in a society demonstrate three main patterns of behavior: indifference, defeatism, and sentimentality. Indifference of religious communities is the result of attitude to society as too involved in sins and evil, to be able to get salvation. Defeatism considers that public social morality is the same as religious morality, and tries to take religious categories of good and evil into social relations. It asks for absolute moral categories in society, and such idealism leads to despair due to obvious contrast between absolute and real. People who think as indifferentists and defeatists, make distinction between holiness and virtues of God, and human secular societies. They consider leaving this world to God's judge, not to salvation. From other hand, sentimentalists derive from modern social optimism and beliefs into civilization's capability to build ideal society by evolutionary way. They also think that society doesn't need salvation because it is good enough to build ideal civilization. Sentimentalism is fruit of liberal theology, and its problem is obscuring social inequalities and cruelties of the world. Though sentimentalists expect to get millennial age evolutionary, all other ideologies, except liberal humanists, are waiting millennial age through apocalypse or God's revelation. The religious nature of millennial and apocalyptic expectations in all ideologies is demonstrated.
\end{abstract}

Keywords: religion, society, contrition, collective egoism, millennialism, Christian realism, Reinhold Niebuhr. 